\title{
Konsep Nilai Islam dalam Nilai Mukemel dalam Sistem Budaya Suku Gayo
}

\author{
Sofyan Abdi \\ Universitas Islam As-Syafi'íyah Jakarta \\ Sofyanabdi.fkip@uia.ac.id
}

\begin{abstract}
Abstrak
Suku Gayo adalah sebuah suku yang mendiami dataran tinggi di wilayah Provinsi Aceh, secara mayoritas masyrakat suku Gayo terdapat di Kabupaten Aceh Tengah, Bener Meriah, Gayo Lues dan Aceh Tenggara yang mayoritas masyarakatnya beragama Islam. masyarakat Gayo sangat fanatik terhadap Agama Islam sehingga adat, budaya dan sistem pendidikan semua berlandaskan Agama Islam. Suku Gayo menggunakan bahasa sehari-hari yang disebut bahasa Gayo yang berbeda dengan suku Aceh. Nilai mukemel adalah nilai tertinggi dalam sistem budaya suku Gayo, nilai mukemel artinya nilai rasa malu Menurut ajaran dalam Agama Islam, manusia selalu berhubungan dengan Allah Swt, manusia dan alam semesta. Mukemel dalam ketiga hubungan itu merupakan satu kesatuan yang tidak boleh dipisahkan dengan fokus mukemel terhadap Allah Swt. Seseorang yang tidak memiliki nilai mukemel (rasa malu) terhadap Allah Swt dan manusia, akan mudah melakukan pebuatan maksiat, pemalas dan sulit untuk mengembangkan dirinya.
\end{abstract}

Kata Kunci: Sistem Budaya Suku Gayo, Nilai Islam, Nilai Mukemel 


\section{A. PEMBAHASAN}

\section{Budaya Suku GAYO}

Suku Gayo adalah sebuah suku bangsa yang mendiami dataran tinggi Gayo di Aceh, yang secara mayoritas terdapat di Kabupaten Aceh Tengah, Bener Meriah, Gayo Lues dan Aceh Tenggara mayoritas masyarakatnya beragama Islam. Menurut Mahmud Ibrahim, masyarakat Gayo sangat fanatik terhadap Agama Islam sehingga adat, budaya dan sistem pendidikan semua berlandaskan Agama Islam. Suku Gayo menggunakan bahasa sehari-hari yang disebut bahasa Gayo yang berbeda dengan suku Aceh (Ibrahim, 2007: 19). Suku Gayo menempati posisi kedua sebagai suku asli terbesar di Aceh. Berdasar perkiraan bahasa Gayo digunakan sekitar 260.000 orang (Eides, 2005; Eades dan Hajek, 2006). Dalam Grammar of Gayo: A Language of Aceh Sumatera dikemukakan bahwa bahasa Gayo termasuk keluarga bahasa Austronesia (Nias, Mentawai, Enggano, dan Batak) dan sebagian besar kosa katanya atau sekitar 40 persen secara leksikal berasal dari bahasa Melayu (Eades, 2005; Melalatoa, 1982).

Masyarakat Gayo merupakan bagian integral dari bangsa Indonesia. Mereka memiliki karakter dan nilai-nilai adat dan budaya yang spesifik sebagaimana masyarakat Indonesia pada umumnya. Nilai-nilai adat istiadat dan budaya Gayo, mereka jadikan sebagai hukum adat (Qanun Kabupaten Aceh Tengah:138). Dalam kehidupan sehari-hari. C. Snouck Hurgronje, mengatakan bahwa, nilai-nilai tradisi masyarakat Gayo yang diungkapkan dalam berbagai pepatah adatnya, jika dilihat sepintas lalu, kadang-kadang mengandung pengertian yang mirip teka-teki. Akan tetapi, bagaimanapun juga kata-kata adat itu merupakan pegangan hukum adat yang harus tetap hidup dan berkembang dalam sendi-sendi kehidupan masyarakat Gayo (Hurgronje, 1996: 7 0-71).

Sistem budaya masyarakat Gayo pada dasarnya bermuatan pengetahuan, keyakinan, nilai, Agama, norma, aturan, dan hukum yang menjadi acuan bagi tingkah laku dalam kehidupan masyarakat (Melalatoa, 1997). Karena itu, hukum adat Gayo adalah aturan atau perbuatan yang bersendikan Syariat Islam dituruti, dimuliakan, ditaati dan dilaksanakan secara konsisten (istiqamah) dan menyeluruh (kaffah) dalam upaya membangun masyarakat Gayo. Dalam perspektif Islam, pembangunan adalah masalah yang aktual sepanjang sejarah manusia. Manusia terus membangun untuk mencapai tarap kehidupan yang lebih baik dan sempurna.

Setiap bangsa, termasuk masyarakat suku Gayo Indonesia terus berlomba untuk mengembangkan kreasi mereka di bidang pembangunan dan kebudayaan, selaras dengan fitrahnya yang hendak maju dan berkembang. Dalam al-Qur'an, Allah SWT., telah memberikan tuntunan terhadap pembangunan. Allah dan rasulNya telah menyuruh umat manusia bekerja keras atau beramal untuk membuat produk kebudayaan baru, membangun dalam segala bidang kehidupan manusia, 
seperti; ekonomi, sosial, budaya, politik, dan teknik, sekaligus berbarengan dengan pembangunan di bidang mental, moral dan spiritual.

Secara kronologis, ada dua pola pembangunan yang diajarkan Islam, yaitu pola hidup bagi kepentingan dunia dan pola hidup untuk kepentingan akhirat. Dengan pola yang dibentangkan Islam tersebut menunjukkan bahwa setiap umat Islam hendaknya mempunyai perencanaan jauh ke depan, melewati jarak kehidupan manusia di dunia ini. la memikirkan kepentingan dunianya yang semu dan pendek ini secara realistis, karena betapapun keadaannya ia hidup di dunia ini. Di samping itu, ia mesti memperhitungkan hidupnya di akhirat atau alam ghaib, yakni dunia baru dan kekal abadi. Bukankah manusia sebelum lahir ke dunia ini berada di alam ghaib. Dari alam ghaib ke alam yang nyata dan kemudian akan kembali kepada alam gaib pula. Dengan demikian, tepatlah apa yang di firmankan Allah SWT., dalam Q.S. Al-Qashash, 28: 77 :

"Dan carilah pada apa yang telah dianugerahkan Allah kepadamu (kebahagiaan) negeri akhirat, dan janganlah kamu melupakan bahagianmu dari (kenikmatan) duniawi".

Berbarengan dengan dua pola hidup itu, maka pembangunan spiritual, moral dan material harus seimbang. Pembangunan spiritual meliputi pembinaan akidah, syariah dan akhlak. Untuk mewujudkan pembangunan spiritual dan moral dalam budaya masyarakat Gayo, maka sangat diperlukan penanaman nilai-nilai adat dan budaya yang relevan dengan hukum Islam dalam berbagai sendi kehidupan masyarakat Gayo. Karena adat dan hukum (edet urum ukum) tidak dapat dipisahkan atau sangat berpadu dalam pembangunan masyarakat Gayo (Ibrahim, 1986: 8).

\section{Sistem Nilai Budaya Suku Gayo}

Nilai-nilai penting dalam adat dan budaya masyarakat Gayo dikenal prinsip bahwa "Edet kuet muperala Agama, rengang edet benasa nama, edet munukum bersifet ujud, ukum munukum berseifet kalam". (Maksudnya adat berjalan dituntun oleh hukum Agama. Adat tidak kuat binasa nama. Adat menghukum bersifat wujud. Hukum Agama itu adalah pasti). "Edet mungenal, ukum mubeza". (Adat mencari mana yang benar dan mana yang salah. Hukum membedakan mana yang benar dan mana yang salah) (Pinan, 2010). Jadi, Adat Gayo berfungsi untuk melaksanakan hukum berdasarkan kenyataan. Sedangkan hukum berdasarkan Firman Allah Swt., dan Rasul-Nya dalam Alquran dan hadis. Hubungan hukum adat dengan hukum Agama sebagaimana dijelaskan oleh Tengku H. Abdullah Husni bahwa, hukum adat dan adat-istiadat menghukum bersifat wujud, artinya kata adat itu selaras dengan ketentuan hukum. Hukum menghukum bersifat kalam, artinya selaras dengan habluminallah. Filsafat hukum ialah adat bersendikan syara', syara' bersendikan kepada adat. Maksudnya adalah adat-istiadat itu tidaklah akan kuat dan kokoh kalau sekiranya tidaklah bersumber kepada syara'. 
Hukum syara' tidaklah akan terwujud dan terealisasi serta menjadi kenyataan dalam kehidupan dan pembangunan masyarakat kalau tidak dijadikan hukum adat sebagai pendukungnya (Husni, dalam Syukri, 2006: 160). Dengan demikian, masyarakat Gayo harus berpegang kepada Hukum Islam dan adat Gayo.

Dalam ungkapan masyarakat Gayo dikenal "Ukum urum edet, lagu zet urum sifet". Artinya hukum dengan adat seperti zat dengan sifat yang sukar dipisahkan (Ali, 1986:1) Karena itu, nilai-nilai budaya masyarakat Gayo tidak terlepas dari ketentuan hukum Islam dan adat-istidat/budaya masyarakat Gayo, seperti; Genap mupakat "syuro" (musyawarah), amanat (amanah), tertib, alang tulung beret bantu (saling tolong menolong), gemasih (kasih sayang), setie (setia), bersikekemelen (kompetitif), dan mutentu (berdayaguna).

Sistem nilai budaya berfungsi sebagai acuan moral dan tindakan, dan digunakan untuk menjaga eksistensi masyarakat. Sistem budaya merangkum seperangkat pengetahuan yang mencakup pandangan hidup, kepercayaan, nilai, norma, peraturan, hukum yang dimiliki masyarakat melalui proses pembelajaran yang kemudian dirujuk untuk mengatur, menilai, dan menafsirkan benda dan kejadian dalam berbagai aspek kehidupan masyarakat. Dengan sistem nilainya, sebuah komunitas membentuk cita-cita dan cita-citanya tentang kehidupan. Menurut Ibrahim (2007: 22) Sistem nilai budaya Gayo mencerminkan konsep ideal karakter yang diharapkan dapat membentuk dan mewarnai pola tindakan masyarakat Gayo. Dengan kata lain, Sistem nilai budaya mencerminkan profil ideal yang diharapkan menjadi fondasi penting dalam pembentukan orang yang dihormati dalam hubungan sosial. Sistem nilai budaya Gayo adalah aktualisasi moralitas (akhlak al-karimah) yang manifestasinya menjadi bagian penting dalam menjaga harga diri. Sistem nilai budaya Gayo terbagi atas nilai-nilai utama dan nilai pendukung (Abdi, Sugiharto, \& Sutoyo, 2019). Nilai utama dalam budaya Gayo disebut mukemel (harga diri), dan untuk mencapai harga diri itu, seseorang harus menerapkan atau mengacu pada sejumlah nilai atau nilai pendukung lainnya. Nilai pendukung ini, yaitu tertib (tertip), setia (setie), kasih sayang (semayang-gemasih) kerja keras (mutentu), amanah, musyawarah (genap mupakat), tolong menolong (alang tulung) dan Kompetitif (bersikekemelen). Untuk mewujudkan nilai-nilai ini dalam mencapai harga diri, mereka harus bersaing. Dan persaingan itu sendiri merupakan nilai budaya, yaitu nilai kompetitif atau bersikekelen yang merupakan nilai penggeraknya. Sistem nilai budaya dapat digambarkan sebagai berikut: 
Gambar 2.1 Sistem nilai budaya suku Gayo

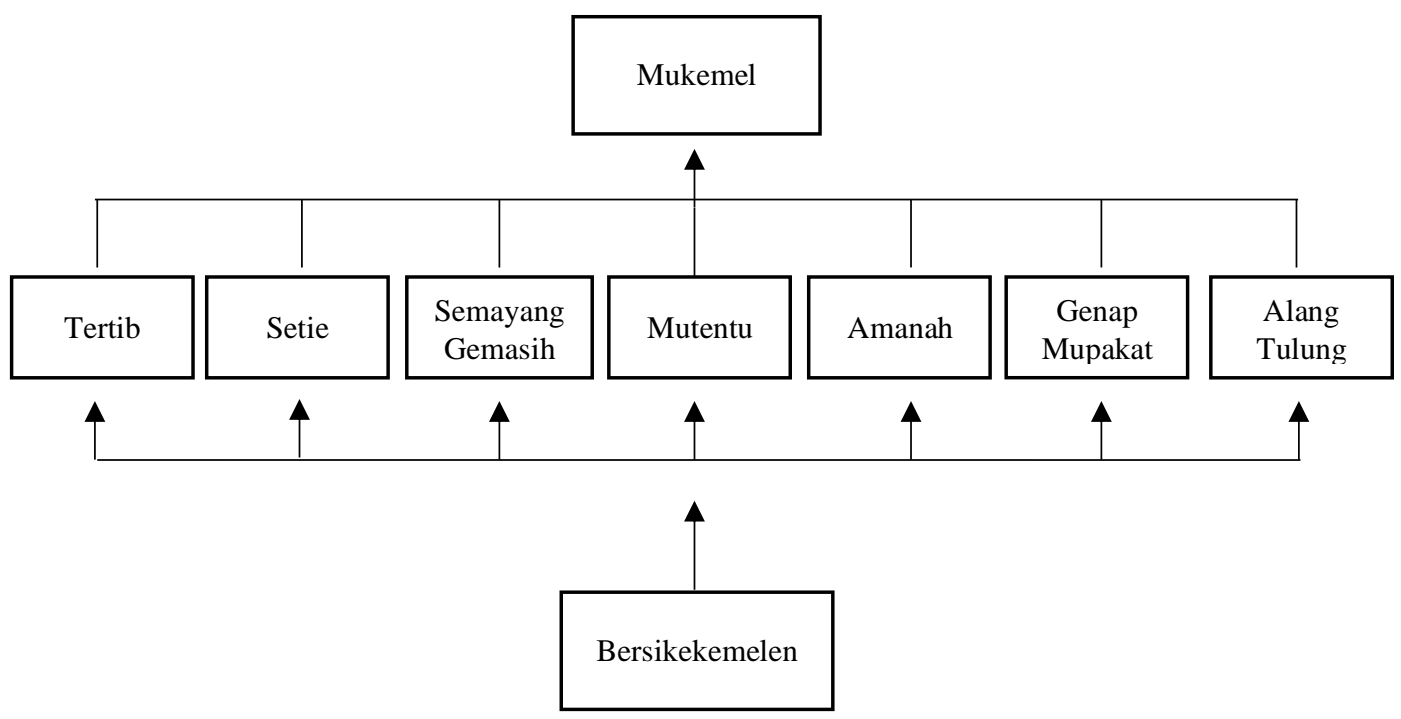

Sumber : Ibrahim dan Pinan (2010: 19)

Gambaran di atas menjelaskan bahwa nilai utama dalam budaya Gayo adalah mukemel (rasa malu), berkenaan dengan harga diri. Kemel pada dasarnya berarti rasa malu sebagai akal sehat, namun dalam aplikasinya yang memalukan itu dipahami dalam pengertian yang lebih luas, sehingga mencakup makna harga diri (iffah). Konsep ini mengacu pada kemampuan untuk menjaga agar dirinya tidak jatuh ke dalam pikiran dan tindakan yang dapat menyebabkan hilangnya harga diri, yaitu tindakan tercela atau yang bertentangan dengan Agama dan kebiasaan.

\section{Konsep nilai Islam dalam Nilai Mukemel dalam Sistem Budaya Suku Gayo}

Nilai mukemel menurut (Ibrahim, 2007: 23) : Mukemel (malu), berkenaan dengan harga diri. Dalam aplikasinya malu dipahami dalam makna yang lebih luas, sehingga mencakup pada makna harga diri (iffah). Konsep ini merujuk pada kemampuan menjaga diri agar tidak terjerumus pada pikiran dan tindakan yang dapat menyebabkan hilangnya harga diri, yaitu perbuatan-perbuatan tercela atau yang bertentangan dengan Agama dan adat.

Menurut ajaran dalam Agama Islam, manusia selalu berhubungan dengan Allah Swt, manusia dan alam semesta. Mukemel dalam ketiga hubungan itu merupakan satu kesatuan yang tidak boleh dipisahkan dengan fokus mukemel terhadap Allah Swt (Ibrahim, 2010: 20). Dalam hadist yang diriwayatkan oleh bukhari dari Abu Hurairah r.a Rasulullah Saw bersabda yang artinya:

"Iman itu bercabang tujuh puluh lebih atau enam puluh lebih, yang paling utama adalah kalimat la illaha illallah dan yang paling rendah adalah 
menyingkirkan rintangan dari jalan, dan malu termasuk cabang dari iman." (HR. Bukhari \& Muslim).

Dalam hadits yang lain, yang diriwayatkan Abu Hurairah radhiallahu 'anhu, dari Nabi shallallahu 'alaihi wa sallam, beliau bersabda:

"Malu adalah cabang dari keimanan." (HR. Bukhari dan Muslim)

Mukemel (rasa malu) mempunyai kedudukan yang tinggi dalam nilai Islam. Malu adalah salah satu sifat terpuji dan sifat orang beriman. Rasa malu mendorong seseorang untuk menjauhkan diri dari perbuatan yang buruk dan sangat bermanfaat dalam mengendalikan hawa nafsu. Orang yang memiliki rasa malu adalah orang yang mampu menjaga diri. Harga diri dan martabat seseorang sangat tergantung pada rasa malu yang dimilikinya. Semakin tinggi rasa malunya, semakin tinggi pula harga diri dan martabatnya. Sebaliknya, semakin rendah rasa malunya, semakin rendah pula harga diri dan martabatnya (Susanti, 2014).

'Malu' dalam bahasa Arab sering diterjemahkan sebagai haya' dan khajal. Kedua-dua perkataan ini sering digunakan silih berganti. Dari Abi Hurairah RA bahawasanya Rasulullah shallallahu 'alaihi wa sallam (SAW) bersabda, "Iman itu terdiri dari enam puluh atau tujuh puluh cabang. Yang paling utama adalah ucapan "Tiada Tuhan yang berhak disembah melainkan Allah", dan yang paling rendah adalah menyingkirkan halangan dari jalan, dan iman adalah satu bahagian dari cabang tersebut. Malu merupakan satu dari cabang iman (Sahih Bukhari, No. 9 dan Sahih Muslim, No. 35). Iman dan rasa malu adalah sesuatu yang tidak dapat dipisahkan kerana ketika rasa malu hilang, maka keimanan seseorang itu juga akan terpengaruhi.

Dari 'Imran bin Hushain radhiyallahu 'anhuma (RA) berkata: Rasulullah SAW bersabda: "Malu itu tidaklah datang kecuali dengan kebaikan". Rasa malu yang positif boleh menjadi pendorong kepada seseorang untuk melakukan perbuatan yang baik dan boleh menjadi faktor pencegah dari melakukan sesuatu perbuatan yang buruk. Malu berfungsi mengawal dan mengendalikan seseorang dari segala sikap dan perbuatan yang dilarang oleh Agama. Orang yang memiliki rasa malu terhadap Allah SWT tidak akan melanggar suruhan Agama. Manakala, orang yang malu terhadap sesama manusia akan menjauhi semua tradisi yang tidak baik dan tidak akan berbuat sesuatu yang melanggar hukum, atau melanggar norma-norma masyarakat (Susanti, 2009). Selain itu juga, rasa malu akan membataskan tingkah laku yang tidak sesuai (Gilliland, 2000).

Dari Ibnu Mas'ud Al-badari RA bahwa sesungguhnya Rasululllah SAW bersabda: " Apabila engkau tidak merasa malu, maka lakukanlah apa saja yang engkau kehendaki" (Shahih Bukhari, No. 6120). Hadis ini menunjukkan bahawa rasa malu sebagai perisai bagi seseorang dari melakukan perbuatan buruk yang boleh memudaratkannya, Agamanya, merusak akhlak dan maruahnya (AsySyaqawy, 2009). Selanjutnya Izard (1977) menyatakan bahawa rasa malu membolehkan seseorang individu untuk membangunkan kemahiran dan 
kebolehan yang diperlukan untuk berfungsi dalam sesuatu kumpulan. Meramalkan rasa malu yang mereka bakal alami akan menyebabkan mereka terbantut dari melakukan perkara yang salah. Seseorang akan menjadi malu untuk melakukan kejahatan kerana mereka tidak mahu dipinggirkan dari lingkungannya. Sebaliknya, khajal adalah malu yang negatif seperti malu dalam menuntut ilmu. Ali bin Abi Talib, Khalifah Islam pernah berkata, "Orang yang tidak tahu, tidak sepatutnya berasa malu untuk bertanya, dan orang yang telah diminta untuk menerangkan tentang sesuatu tidak perlu malu untuk mengatakan dia tidak tahu jika dia tidak tahu jawapan kepada soalan "(Al-Muqaddam, 2004).

Menurut Mastor (2006) rasa malu yang membawa makna yang buruk ialah malu sebagai perasaan yang mendorong munculnya sifat tidak positif, seperti malu bertanya, malu mengemukakan pandangan, malu mengingatkan yang salah, dan sebagianya. sayangnya, banyak orang yang gagal untuk menghilangkan rasa malu, terutama apabila ia sedang dalam proses mencari ilmu. Satu lagi jenis malu yang negatif ialah malu yang menghalangi seseorang untuk melakukan kebaikan. Malu yang negatif merujuk kepada rasa malu dalam mengatakan kebenaran, malu melakukan sesuatu kebaikan, malu dalam menimba ilmu pengetahuan, malu dalam bertanya dan menjawab pertanyaan, malu dalam menyampaikan pendapat dan malu dalam mempertahankan hak. Seseorang itu tidak perlu malu untuk menuntut apa yang memang menjadi haknya. Tapi, ia seharusnya malu jika mengambil apa-apa yang bukan haknya, walaupun dalam keadaan di mana tiada orang lain yang mengetahui perbuatannya (Susanti, 2014).

Orang yang tidak mempunyai sifat malu akan bebas melakukan apa saja yang diinginkan hawa nafsunya dan tidak akan menghiraukan apapun keburukan yang dilakukannya (Asy-Syaqawy, 2009) dan ia boleh merosakkan peradaban masyarakat. Oleh yang demikian, memerangi rasa malu yang negatif merupakan asas yang sangat penting dalam mencapai kesihatan mental dan meningkatkan keyakinan diri. Seseorang yang tidak memiliki nilai mukemel (rasa malu) terhadap Allah Swt dan manusia, akan mudah melakukan pebuatan maksiat, pemalas dan sulit untuk mengembangkan dirinya. karena ketika dia tidak memiliki nilai mukemel harga diri pasti akan merosot dan dipandang rendah serta hilangnya kewibawaan dihadapan orang lain termasuk di hadapan keluarga (Ibrahim, 2010: 21). Sebaliknya jika seseorang memiliki nilai mukemel dan mampu mengimplementasikannya dalam kehidupan sehari-hari harga diri dan penghargaan lingkungan jga akan semakin meninggi karena dengan nilai mukemel seseorang dapat menghindari perilaku yang tidak sesuai dengan nilai Agama.

\section{B. Kesimpulan}

Dalam sistem nilai budaya suku Gayo terdapat 9 nilai, salah satu nilai tersebut adalah nilai mukemel (rasa malu). Dalam pandangan nilai Islam rasa malu mempunyai kedudukan yang tinggi. Malu adalah salah satu sifat terpuji dan sifat 
orang beriman. Rasa malu mendorong seseorang untuk menjauhkan diri dari perbuatan yang buruk dan sangat bermanfaat dalam mengendalikan hawa nafsu hal ini sesuai dengan pandangan dalam budaya suku Gayo yang menyatakan bahwa jika seseorang memiliki nilai mukemel dan mampu mengimplementasikannya dalam kehidupan sehari-hari harga diri dan penghargaan lingkungan juga akan semakin meninggi karena dengan nilai mukemel seseorang dapat menghindari perilaku yang tidak sesuai dengan nilai Agama. Nilai mukemel menjadi salah satu acuan bagi tindakan dalam berbagai aspek kehidupan masyarakat Gayo. Nilai hukum adat dalam masyarakat Gayo harus dipertahankan dan dijaga, karena prinsip-prinsip adat itu menyangkut pada harga diri, dalam pandangan Islam pun nilai-nilai hukum adat dalam masyarakat Gayo itu sangat positif, sebab antara nilai-nilai adat dan syariat tidak dapat dipisahkan dalam mencapai kemaslahatan dalam berbagai aspek kehidupan. Islam memandang bahwa nilai-nilai adat dan budaya itu sangat penting dalam memperkokoh keimanan dan meningkatkan kualitas ketakwaan.

\section{Daftar Pustaka}

Abdi, S., Sugiharto, D. Y. P., \& Sutoyo, A. (2019). Group Guidance Based on Gayo Ethnics' Cultural Values to Improve Students' Islamic Characters. Jurnal Bimbingan Konseling, 8(2), 112-118.

Al-Bukhari, Abu Abdullah Muhammad bin Ismail. (2011) Ensiklopedia Hadits; Shahih al-Bukhari 1, Terj. Masyhar dan Muhammad Suhadi, Jakarta: Almahira.

Amin Abdullah Asy-Syaqawy. (2009). Kitab Al-Haya'. Darus sa'adah.

Al-Qur'an dan Terjemahan. (2017). Kementrian Agama Republik Indonesia.

Ali, Abdurrahman Ali. (1986). Peranan Islam Melaui Adat Gayo Dalam Pembangunan Masyarakat Gayo. Makalah Seminar Ilmu Pengetahuan Dan Kebudayaan 20-24 Januari.

Eades, Domenyk. (2005). A Grammar of Gayo: A Language of Aceh, Sumatera. Canberra: The Australian National University.

Eades, Domenyk., Hajek, John. (2006). “Gayo" dalam Journal of the International Phonetic Association. 36 (1). 107-115.

Emilia Susanti. (2014). Budaya malu cerminan bagi perempuan melayu. Sosial Budaya: Media Komunikasi Ilmu-IImu Sosial dan Budaya, 11 (2).

Gilliland, R. (2000). The roles of shame and guilt in hypersexual behavior. All Theses and Dissertations. Paper 2568, Brigham Young University. 
Hurgronje, C. Snouck. (1996). Tanah Gayo dan Penduduknya. Terj. Budiman S. Jakarta: INIS.

Ibrahim, Mahmud. (1986). Syariat Dan Adat Istiadat. Takengon: Yayasan Maqamam Mahmuda.

Ibrahim, Mahmud (2009). Syariat Dan Adat Istiadat. Takengon: Yayasan Maqamam Mahmuda.

Ibrahim, Mahmud., Pinan, A.R.Hakim Aman. (2010). Syari'at dan Adat Istiadat. Takengon: Maqamam mahmuda.

Izard, C., E. (1977). Human emotions. New York: Plenum Press.

Mastor. K.A (2006). Personaliti Malu dan Psikologi Membuat Keputusan di kalangan Pelajar Melayu. Jurnal Pengajian Umum. 7, 67-80.

Melalatoa, M.J Dkk. (1985). Kamus Gayo-Indonesia. Jakarta: Pusat Pembinaan dan Pengembangan Bahasa.

Muhammad Ahmad Ibnu Isma'il al-Muqaddam. (2004). Konsep malu dalam Islam. (lyoh Masruroh Daud, Trans. Jakarta Timur: Pustaka al-Kautsar.

Syukri, Sarakopat. (2006). Sistem Pemerintahan Tanah Gayo Dan Relevansinya Terhadap Pelaksanaan Otonomi Daerah. Jakarta: Hijri Pustaka Utama. 